\title{
REVERSES OF ANDO'S INEQUALITY FOR POSITIVE LINEAR MAPS
}

\section{YUKI SEO}

Abstract. Ando's inequality says that if $A$ and $B$ are positive operators on a Hilbert space $H$ and $\Phi$ is a positive linear map, then for each $\alpha \in[0,1]$

$$
\Phi\left(A \sharp_{\alpha} B\right) \leqslant \Phi(A) \sharp_{\alpha} \Phi(B)
$$

where the $\alpha$-geometric mean is defined by

$$
A \sharp \alpha B=A^{\frac{1}{2}}\left(A^{-\frac{1}{2}} B A^{-\frac{1}{2}}\right)^{\alpha} A^{\frac{1}{2}} .
$$

In this paper, we give simple proofs of reverse Ando's inequalities: If $A$ and $B$ are positive operators such that $m A \leqslant B \leqslant M A$ for some scalars $0<m \leqslant M$, then for each $\alpha \in[0,1]$

$$
\Phi(A) \sharp_{\alpha} \Phi(B) \leqslant \Phi\left(A \sharp_{\alpha} B\right)-C(m, M, \alpha) \Phi(A)
$$

where the Kantorovich constant for the difference $C(m, M, \alpha)$ is defined by

$$
C(m, M, \alpha)=(\alpha-1)\left(\frac{M^{\alpha}-m^{\alpha}}{\alpha(M-m)}\right)^{\frac{\alpha}{\alpha-1}}+\frac{M m^{\alpha}-m M^{\alpha}}{M-m}
$$

for any real number $\alpha \in \mathbb{R}$.

Mathematics subject classification (2010): 47A63, 47A64.

Keywords and phrases: Positive operator, geometric mean, positive linear map, generalized Kantorovich constant, Cauchy-Schwarz inequality.

\section{REFERENCES}

[1] T. Ando, Concavity of certain maps on positive definite matrices and applications to Hadamard products, Linear Algebra Appl., 26 (1979), 203-241.

[2] T. ANDO, Reverse Hölder inequality via $A-G$ inequality, a private note.

[3] J.-C. Bourin, E.-Y. LeE, M. Fujil AND Y. SEO, A matrix reverse Hölder inequality, Linear Algebra Appl., 431 (2009), 2154-2159.

[4] M. FujII, E.-Y. LEE AND Y. SEO, A difference counterpart to a matrix Hölder inequality, Linear Algebra Appl., 432 (2010), 2565-2571.

[5] T. Furuta, J. Mićić, J.E. PeČArić And Y. Seo, Mond-Pečarić Method in Operator Inequalities, Monographs in Inequalities 1, Element, Zagreb, 2005.

[6] F. Kubo And T. Ando, Means of positive linear operators, Math. Ann., 246 (1980), 205-224.

[7] E.-Y. LEE, A matrix reverse Cauchy-Schwarz inequality, Linear Algebra Appl., 430 (2009), 805-810.

[8] J. MićIĆ, J. PEČARIĆ AND Y. SEO, Complementary inequalities to inequalities of Jensen and Ando based on Mond-Pečarić method, Linear Algebra Appl., 318 (2000), 87-107. 